\title{
Future scenarios for post-industrial Eindhoven. A fringe-belt perspective
}

\author{
Daan Lammers, Ana Pereira Roders, Pieter van Wesemael \\ Department of the Built Environment. University of Technology Eindhoven. The Netherlands \\ E-mail: d.g.o.lammers@tue.nl
}

\begin{abstract}
Research Although fringe-belt analysis is increasingly recognized as sound baseline for research to inform the operational level of spatial urban planning, e.g. urban management plans, little research has yet focussed on its potential on the strategic level of spatial urban planning. In general, strategic urban planning is dominated by quantitative and economically based modes of scenario analysis. More qualitative analytical approaches, such as provided by morphogenetic analysis, are usually playing a minor role if any at all. This paper aims to discuss the potential role and contributions of fringe-belt analysis to strategic spatial scenario planning. For that a plural case study is carried out based principally on fringe-belt analysis in the former industrial region of Eindhoven, The Netherlands. Multiple roles of the present urban fringe-belt composition in the anticipated scenarios of future transformation of the urban region are explored, building on the potential internal modification processes within its fringe-belts to adapt the city to these scenarios. Research outcomes are critically related to the current strategic vision of the city and urban region, to come up with recommendations to come to a more integrated, effective and authentic strategic approach. A pro-active approach towards fringe-belt modification is suggested as efficient urban development strategy, for example, channelling the increasing pressure of intensification of land-use (controlled fringe-belt alienation), or, creating social and economic value by means of fringe-belt adaptation. Results contribute to the debate on fringebelt development and future transformation in the case of former industrial and post-industrial cities and urban regions, and more specifically, on the distinctive character and role of radial fringe-belts, radial fringe-belt corridors and radial fixation lines, within the changing spatial configuration of the social and economic urban stratification.
\end{abstract}

Keywords: fringe-belt analysis, strategic planning, scenario planning, radial fringe-belts, Eindhoven.

\section{Introduction}

Many post-industrial mid-sized city still struggle with the effects of the deindustrialisation from the late 70's on, trying to develop new promising socio-economic development paths to revitalise the city, its economy and community, and seeking for new roles or specialisations within the global economic network fitting to their specific strengths in terms of demographic, economic, cultural as well as spatial characteristics (Sassen, 2001). After all different types of cities (based on cultural region, functional structure, social, economic and institutional structure, geographical structure, size, form, history, etc.) respond very differently to the complex and dynamic configuration of global and general trends and processes of the post-industrial era. Specifically for former (specialized) industrial towns and cities, spatial planning for the uncertain future has a strong 
physical dimension, simply because of the fact that a substantial part of its built-up area consists of former industrial sites, containing large amounts of infrastructure, that has fallen into disuse, and abandoned buildings. Typo-morphological analysis enables us to understand the role of space into the cities historical evolution but also to understand the characteristics new developments can build on. 'Urban projects embody an important paradigmatic shift in urban planning from master planning / regulatory planning to strategic planning with a clear emphasis on implementation' (Albrechts, 2006, p.1494). Strong complementarity of planning and urbanism is recognized in their approach: the first often more model-based and viewing from a top-down perspective, the second more casuistic and based on bottom-up experiences (Albrechts, 2006). However, since 'the death of the urban masterplan', in many European urban regions the qualitative morphological dimension of urban planning, specifically with concern to the scale of the entire city or sizable part of the city, seems to have been eroded away (relate to Dutch MIRT). This has generated a gap of topical morphological knowledge between the level of corporate urban ambitions and the implementation level of 'small urbanism' (Scheer, 2013). That void is now found partly filled with a new managerial and administrative machinery and has formed a playing field for neo-liberal forces (Lammers et al., forthcoming; Albrechts, 2016; Wagenaar, 2011). The lack of topical morphological knowledge of the larger urban-geographical scale deprives urban planners and designers of an important analytical key that should work to ground new (strategic) projects in the urban community and its history (Scheer, 2013). For multiple reasons, the historico-geographical concept of the urban fringe belt could be suggested as a promising analytical tool to fill that knowledge gap.

\section{Urban fringe belts and urban planning}

Many of the current urban projects in European cities, particularly in former industrial cities, still relate to post-industrial recovery and to urban renovation: the sustainable revitalisation of what in the post-industrial era have become obsolete brownfields. Although this 'project of projects' has many dimensions (De meulder et al., 2004, Busquets, 2001, 2011) it essentially concerns 'the spatial impact on the physical environment of proposals for new development and the spatial coordination of the various functions and activities that they would require in relation to the urban fabric' $(\mathrm{Gu}, 2014$, p. 267). Substantial parts of the geographical patterns of former industrial sites in cities refer to former peripheral locations where, once, during periods of relative stagnation of compact (residential) urban expansion, extensive land uses acquired cheap land. As such, to a large extend, the current issue of post-industrial recovery and physical urban renovation directly relates to the historicogeographical topic of the urban fringe belt (M. R. G. Conzen, 1960, 1981; Gu, 2010, 2014). This notion forms one of five main reasons that account for recent developments of fringe belt theory, focussing on the role of fringe belts in the urban planning context (M. P. Conzen, 2009; M. P. Conzen et al., 2012; Whitehand et al., 2012; Whitehand \& Morton, 2003, 2004, 2006; Gu, 2010, 2014; Ünlü, 2013).

A second and third notion frames the position of the fringe belt within recent compact city policy. On the one hand the related debate denounces the diffusion and fragmentation of the contrast between city and country land (e.g. green belts, see Whitehand \& Morton, 2004); on the other hand it relates to urban environmental and sustainability challenges (see a.o. Hopkins, 2003); fourthly, fringe belts are involved in the discourse about urban landscape transformations under the conditions of globalization, intercity competition and post-modernity (Gospodini, 2006); and fifthly, from a specific areal development point of view, the urban fringe belt has been identified as an autonomous and independent historicogeographical zone, neither considered from a city perspective nor from a country side perspective, containing its own (intrinsic) developmental logic (Suurenbroek, 2009). Although many studies succeed to reveal the relevance and to stress the urgency for integration of larger morphological and 
historico-geographical structure of cities as entities, into spatial planning contexts, the next question of how to integrate it strategically into a urban planning context is for a large part still remaining.

Therefore, in this paper, the application of the fringe belt approach in strategic urban planning is explored. It seeks to understand how the concept could be integrated into a prognostic research approach. This means that the study is primary a methodological investigation. The general aim is framed by the casuistry of the European, medium sized, former industrial city, represented by the case of Eindhoven (The Netherlands, Southeast North-Brabant). Specific research questions are formulated for the case study.

\section{Post-industrial Eindhoven}

Eindhoven started to develop rapidly as an industrial town since 1891, when 'Philips Gloeilampen NV' founded in the historic urban core. Before that time Eindhoven was no more than a small agricultural town, with about 5000 inhabitants. The city grew out to the fifth city of The Netherlands, with almost 225.000 inhabitants in 2016. As such, the city can best be categorized as biggest mediumsized city of the country. Eindhoven is situated in the southeast of the province of North Brabant (figure $\mathrm{x}$ ), at some $100 \mathrm{~km}$ east of the Randstad, and at similar distance to the German Ruhr area in the east and the Belgian cities of Brussels and Antwerp in the south. Most commonly the Eindhoven region is defined as the Metropolitan Region Eindhoven (MRE; formally SRE), consisting of 21 municipalities, together counting almost 750.000 inhabitants. Since a serious economic crisis hit the region in the early 1990's, several economic stimulus programs were launched to strengthen the regional economic structure, currently having led to the officially recognized status of the national Brainport (Van den Berg and Otgaar, 2012; Brainport, 2016). From a national (Dutch) perspective the Brainport concept actually refers to the Mainport (Amsterdam and Rotterdam) status as it was defined in the
Fourth Memorandum on Spatial Planning, published in 1988. This memorandum marked a shift at that time from a mainly socially engaged spatial policy to a strong economic focus. In that view urbanity was promoted as a physical and spatial condition that should stimulate economic revitalization (Wagenaar, 2011, p. 514).

Currently, one of the main concerns of the Brainport City Eindhoven is the critical relationship between, on the one hand, the it's prominent status of generally being recognized as one of the most innovative regions of Europe, owing this position to the presence of innovative companies and some renowned knowledge institutions, and on the other hand, the balance of factors that keep the region in that fortunate position. Central to that concern is the fear that the general living conditions in the region aren't attractive enough for corporate staff and excellent skilled knowledge workers to align Brainport Eindhoven with global competitiveness (Lammers et al., forthcoming). The city chose to approach this challenge by working towards 'a quantum leap in metropolization' (BVR, 2014), somehow in line with the approach followed in the Fourth Memorandum. The official recognition as the Dutch main knowledge hub, as of fundamental relevance for the national economy, has substantial implications for the city's urban planning context. With this paper we seek to illustrate an alternative morphological and empirical view, opposing the prevailing economic and managerial view.

\section{Morphological context: Eindhoven's fringe- belts}

Although officially registered as a city since 1232 Eindhoven didn't experience substantial outward growth until the second half of the nineteenth century, when it started to develop as an industrial town. The industrial expansion of Eindhoven consists of four morphological periods: early industrial (1850-1920), heydays of industry (1920-1940), late industrial (19451970) and post-industrial (after 1970). Each period has been characterized by distinctive planning regimes observable in the urban 
Table 1. overview of Eindhoven's fringe-belt structure

\begin{tabular}{lll}
\hline Fringe-belt & form & type \\
\hline Inner fringe-belt & Tangential & $\begin{array}{l}\text { Pre-industrial; fixation line: former city canals and } \\
\text { ramparts (Vestdijk, Keizersgracht, Wal); }\end{array}$ \\
\hline $\begin{array}{l}\text { Middle fringe- } \\
\text { belt }\end{array}$ & Radial & $\begin{array}{l}\text { Early industrial; morphological framework: pre-urban } \\
\text { street network, geo-/hydro-morphological conditions }\end{array}$ \\
\cline { 2 - 3 } Outer fringe-belt & Rangential & $\begin{array}{l}\text { High / late industrial; fixation line: middle ring road } \\
\text { (Rondweg) }\end{array}$ \\
\cline { 2 - 3 } & Radial & $\begin{array}{l}\text { High industrial; morphological framework: } \\
\text { multifunctional, industrial arterial infrastructure (canal, } \\
\text { railway, streets) }\end{array}$ \\
\cline { 2 - 3 } & Tangential & $\begin{array}{l}\text { Late industrial; morphological framework: Dommel } \\
\text { valley }\end{array}$ \\
\hline & $\begin{array}{l}\text { Late industrial; fixation line, morphological framework: } \\
\text { west-side highway ring road, canal }\end{array}$ \\
\hline
\end{tabular}

(Source: own elaboration)

Table 1. Overview of Eindhoven's fringe-belt

fabric. Related to the shifts between those systems a specific fringe-belt configuration has developed, consisting of six typologically distinct morphological categories (table 1). Recent study has defined the relationship between Eindhoven's form of growth and the form of its fringe-belts (Lammers, et al., 2016, forthcoming $a, b)$. A most striking aspect with regard to Eindhoven's urban growth history is the phenomenon of radial urban growth and the formation of radial fringe belts.

\section{Methodology}

The central question how to apply the fringe belt approach in strategic urban planning is explored from two perspectives. (1) the analytical value of the urban fringe belt is investigated, following naturally from the conception of the concept a 'historicogeographical frame of reference within which the phases of development, and physical forms, of previous societies are related to the physical configurations of present cities' (Whitehand and Morton, 2004), towards a similar but now future-oriented analytical concept; (2) the strategic value of the urban fringe belt for the future development of a city (Eindhoven) is explored, relating the characteristics of the phenomenon as a total morphologicalgeographical configuration and its constituent parts (M. P. Conzen, 2009; Gu, 2014; Hopkins, 2004; Kropf, 2001) to the specific challenges that meet a specific type of city (a European, mid-sized former industrial city).

Methodologically the study builds on previous fringe-belt analyses such as the one on Birmingham's Edwardian fringebelt (Whitehand and Morton, 2003, 2004, 2006) and the (comparative) case study of the waterfront areas of Auckland and Wellington, New Zealand (Gu, 2010, 2014). These studies intended to explore fringe belts in order to inform decision makers and decision-making, to plan-making and development control. In this paper, aiming to explore the integration of the fringe belt concept into a strategic planning context, the main focus will be on the factors that account for the survival of the fringe belt units (Whitehand \& Morton, 2004, p.276). In fact, being concerned is the balanced complex of factors (BCF) which keeps a (fringe belt) plot in any given use. That balance may be related to social, economic and politicalinstitutional variables, but these are in turn generally related in some way to locational variables (Whitehand, 1967, p.232-3). From an evolutionary perspective, or 'through the lens of path dependency' (Zarina, 2013, p.356), the fixity of the BCF within a transformative urban context represents the rationales (relevance) of the plots or plan units for the current and next historical era (post-industrial morphological 
periods). This leads to the assumption that those understanding of the BCF's are of strategic value for the future development paths of the city.

Previous research on the formation and modifications of Eindhoven's fringe belts is taken as a starting point to identify, describe and contextualize the BCF's. Via the detailed investigation of several topical cases of fringe belt modification trends, the related BCF's are decomposed into their social, economic and political-institutional and locational variables to create a platform for cross-relating urban morphology to the variables that constitute the top down formulated corporate image of the city (Oliveira, 2016; Whitehand, 2010). Framing a scope for this paper we chose to focus in particular on the ambition to spatially prepare the city for a substantial increase of inhabitants as described in the city's housing vision (Eindhoven, 2014), which is directly related to the city's Brainport status and the consequential conformation to the MIRT protocol (see above).

The cross relation of bottom-up morphogenesis and the top down formulated urban ambitions could lead to sets of multiple micro scenarios per case. The idea is then, that, building further on those flexible sets, larger and higher level urban scenarios can be composed in multiple and flexible arrangements. These scenarios can be applied within multiple types of strategic planning processes. For instance they can be used in a participatory planning context (Secchi and Viganò, 2009; Chakraborty \& McMillan, 2015; Zapata \& Kaza, 2015); or to integrate more flexibility in the process, for instance by the application of 'by-passes' (see Viganò, referred to in Peleman \& Pelger, 2015), or by providing a plural alternative to commonly use of one preferred scenario (Zapata \& Kaza, 2015; Chakraborty \& McMillan, 2015).

\section{Results}

The basic taxonomy of Eindhoven's fringe belts (table 1) strongly correlates with the spatial division of the different types of balanced complexes of factors which keep the fringe belt plots in their use (BCF's). In this section, firstly four types of complexes will be described and parsed into their economic, social, cultural and political-institutional dimensions, and linked to the specific (local) types of fringe belts; then concluding the cross-linking between bottomup morphogenetic evidence and top down formulated housing vision will be illustrated and discussed.

\section{Balanced Complexes of Factors}

(1) the first BCF is described as 'the locational inertia induced by increased investment in sites' (Whitehand \& Morton, 2004). This concerns the fact that when a city grows, the relative centrality and the land value of a fringe belt plot increases. Then the continuation of the fringe belt land use can only be justified by intensification of use, which implicates capital investment in additional buildings (Whitehand, 1972). These findings were basically related to research of public institutional plots and land uses. When applying the theory specifically to industrial fringe belts, as is the case in Eindhoven, several notes have to be considered. Most relevant in this is the fact that, although also public institutions experience operational changes in time due to societal and political shifts that may affect the economic justification of the use and possession of their buildings and land (e.g. the alienation of the site of the inner city municipal hospital in the eastern part of Eindhoven's IFB into CBD land use), for private fringe belt land uses (such as industrial land uses and to a certain extend also private institutions) the impact of sectorial shifts in the economy is a much larger and more fundamental. In Eindhoven particularly the high industrial radial OFB has experienced the effects of the disruption of the balanced complex of factors that accounted for the continuity of the type of land use (the industrial crisis). The industrial land use in especially the western fringe belt corridor has almost completely transformed into other types of land use, partly adapted to other fringe belt land uses, partly alienated. The primary economic value of the buildings and infrastructural elements had diminished substantially and is translated into a rather 
socio-cultural value. The eastern corridor has until now still hardly been affected by fringe belt modification. Only where the corridor merges with the eastern part of the tangential IFB most fringe belt units have been alienated into compact typologies of residential land use. (2) A second complex of factors of inertia is the 'dependence on fringe-belt features that develops among other land users in the vicinity' (Whitehand \& Morton, 2004). This complex concerns situations where fringe belt land use units are, in addition to a physical embedding, also are deeply integrated into the social, cultural and economic structures of the surrounding urban fabric. Whenever the continuation of land use of these units is challenged, involved agencies easily develop into the formation of local pressure groups (Whitehand \& Morton, 2004). In Eindhoven these situations are mainly observed in the early industrial radial MFB. In these cases often tactics of informal claiming of space are involved.

(3) The third complex is the 'limited rationality of the plot'. This type of complex refers to the view that the contemporary urban landscape is the product of an accumulation of individual decisions by private bodies, businesses and authorities, each answering to their own 'minimal rationality' (Ryckewaert, 2002 referring to Secchi, 1996). However, in this case the issue of minimal rationality is viewed from the perspective of urban form. The concept is based on the situation in which a land use experiences protection to change based on the fact that the plot form and size doesn't meet the general requirements for the realization of building types that serve more intensive land uses (see also Apostel et al., 2008). The strength of this factor depends on the typological variety of demand for housing in an urban region, so strongly related to a region's economical and societal structure. In Eindhoven these situations are mainly observed in the early industrial radial MFB.

(4) the fourth complex is the "contrast in plotsize-variety'. This concerns the contrast in plot sizes between larger fringe belt plots bordered by multiple small adjacent plots (Whitehand \& Morton, 2004). This complex is mainly morphologically defined, but is strongly linked to the socially, culturally and economically embedding of the land use in the surrounding urban fabric (complex 2).

\section{Micro cases and sub-scenarios}

The micro case study concerns a comparison between four fringe belt units of the early industrial radial MFB, situated in two different corridors: the MFB corridors of the districts of Stratum (the 'Museum quarter'-unit) and of Gestel (the 'Bergstraat'-unit, the 'Palingstraat'unit and the 'Hallen'-unit), two on a similar distance close to the CBD (Museum quarter and Bergstraat) and two at a distance to the CBD of respectively about half a kilometre (Palingstraat) and one kilometre (Hallen-unit) (figure $\mathrm{x}$ ). We found significant difference in the way how those three perimeter blocks respond to the increasing transformative pressure that they all experience. These differences are found being clearly based on the differences in typomorphological and land use configurations to which they have evolved from their formation onwards. Most characteristic in this is the changing relationship between the perimeter plot series and the internally situated plots that they surround. The two BCF's involved are the limited rationality of the internal plots and the extreme plot-size-variety.

The radial MFB is constituted of a radially distributed series of primary and secondary perimeter blocks which morphologically relate to the typical forms and measurements of the antecedent rural framework of the streets, paths and routes. The larger internally situated plots, that are surrounded by perimeter plot series facing the public domain of the street network, exhibited limited rationales for residential urban development within the relatively narrow local scope of demand for typological variations during the industrial phases of urban growth (a prevailing demand for ground-floor family housing with back gardens). Due to this limited rationality for residential development the land market value of those larger plots was relatively low and thus accessible for a certain scope of fringe belt land uses (Lammers et al., 2016, forthcoming). This stable frame of factors got disturbed when the demand for 
typological variation expanded during the last decennia of the post-industrial era. This is illustrated by the micro cases. The inner block plots of the Museum quarter-unit are recently alienated from their fringe belt land uses (originally suburban villa plots and industrial plots) into an ensemble of small household apartment buildings above an underground parking (ca 90 dwellings/ha) and several built extensions of hotels, situated along the radial urban exit route (Stratumsedijk - Aalsterweg Leenderweg). The definitive modification had been preceded by a process of urbanization of the perimeter plot series, as most of the suburban (manufacturer's) villas transformed into offices and hotels. Although the final modification of the fringe belt unit still met substantial resistance from surrounding land users, it can be reasonably assumed that, besides the change in the limited rationality for development on the fringe belt plots, also the urbanization of the perimeter plot series has played a crucial role. This relates to a second complex of factors of resistance, this time caused by the high contrast in plot-size-variety. That contrast was reduced in two ways, firstly, due to the fact that plots of the perimeter series were joined with the internal plots (hotel extensions) and secondly, that the intensification of the inner area increased the functionality of the land uses on the perimeter plot series, for instance through the development of an underground parking space partly available for the offices in the perimeter.

All the negotiations that led to the final business case for the development were part of the urban planning process. Within that process, where several parties were involved (land owners / entrepreneurs with their architects, a management office, urban designer and the municipal authority), considerable attention was paid to the development of projectspecific morphological regulations. Most relevant from that perspective was, firstly, the idea to link the maximum height of the internal plot development to the un-visibility of the building masses viewed from the public domain (the surrounding streets), which exhibits intentions of streetscape conservation; secondly, a level playing field was created for following individual development initiatives on other internally located plots in the block, by designing regulations that should account (guarantee) for the autonomy of each new project. This was translated into the prescription that new buildings had to be situated along the plot border line, with their front facades oriented inwardly (back to back development). From the comparison to the recent transformations of the three cases in the fringe belt corridor of Gestel some significant differences can be highlighted. For instance when concerning the limited rationality of the Bergstraat-unit, the stable frame of factors also got disturbed. This time under influence of the increasing functional differentiation of the CBD. However, here, the development of a hotel on the internal fringe belt plot of a former match factory met relatively stronger opposition as the perimeter plot series contain fewer CBD land uses (office villas and hotels) and more residential use. In this case the contrast in plot-size-variety proved to be a much stronger resistant factor than at the Museum quarter development. Another striking factor was the informal claiming of the plot by the people living in the neighbourhood, who used it for years as an urban allotment garden (de Bergse Tuinen). In the longer run the resistant factors didn't turn out to be able to keep the use of the fringe belt unit as the developers found themselves confirmed in their intentions by municipal policy. But the course of the process indicates a certain areal condition where factors that account for the surviving of the radial fringe belt corridor seem to be broadly integrated into the historico-geographical structure of the corridor. This indication is emphasized by the cases of the Palingstraatunit and the Hallen-unit. The first unit contains an internal block park: De Vergeten Tuin (the Forgotten Garden), which is also a plot claimed by neighbouring residents. The site is managed by a legalized group of squatters which occupy an old factory building (owned by the municipality), situated at the perimeter of the block on the side of the Palingstraat. The garden is open for the public on regular basis. Many of the back gardens of adjacent houses in the block perimeter are openly connected to the park. 


\section{Conclusion}

The findings presented can be synthesized into two main hypotheses which can form the basis of the higher level strategic scenarios. Firstly, it can be argued that for all primary and secondary perimeter blocks of the total early industrial radial MFB, to more or less extend, the limitation of the developmental rationales regarding to the modification of its units is decreasing due to the general as well as regional societal changes (for instance the general increase of smaller households in cities and, for Eindhoven, the increasing diversification of its social structure, both driving an increasing demand for typological variation in housing). This drives on a new level, other complexes of factors to take over the account to keep the fringe belt plots in their current use. For instance the contrast in plot-size-variety and the dependence on fringebelt features that develops among other land users in the vicinity. Both of these complexes concentrate on the relationship between the internally located fringe belt plots and the perimeter plot series of the blocks, however in a different way than before. On the one hand, this new relationship changes the way how the existing city responds to new economic, societal and cultural influences, and on the other hand, it brings other intrinsic differences to the surface.

This introduces to the second conclusion, concerning the thesis that the currently prevailing compact and concentric spatial policy model as presented in the strategic housing vision (Eindhoven, 2014) doesn't match with the empirical model. Although situated on a similar distance to the CBD as the Bergstraat-unit, which alienation process experienced substantial governmental involvement, the Museum quarter-unit showed to be modified largely in harmony with the longer term transformation of the area. Although this resulted in an alienation of the fringe belt unit, morphologically the structure still expresses a clear and attractive typological distinction of the urban structure. For the units of the Gestel fringe belt corridor it is suggested to apply a different planning approach. There the factors that account for the surviving of the radial fringe belt corridor seem to be integrated more broadly into the historico-geographical structure of the corridor, which somehow accounts for a valuable sustainable areal urban condition.

In general it is concluded that the integration of a historico-geographical or, particularly in the case of the European, mid-sized former industrial city, a fringe belt approach into a strategic planning context can substantially improve the path towards developing an urban environment for an excellent and authentic quality of live, and with that the strategic value of a cities intrinsic character profile, as a base for spatial distinctiveness. This would anyway make the general claim of many strategic planners to build on a cities DNA a much more plausible one.

\section{References}

Architectuurcentrum Eindhoven (2005) Supervillage; plan de campagne (ACE, Eindhoven).

Atzema, O., Rietbergen, v. T., Lambooy, J. \& Hoof, v. S. (2012) Ruimtelijke economische dynamiek. Kijk op bedrijfslocatie en regionale ontwikkeling (Coutinho, Bussum).

Barke, M. (1974) 'The changing urban fringe of Falkirk: some morphological implications of urban growth', Scottish Geographical Magazine 90, 85-97.

Barke, M. (1982) 'Beyond the urban growth map: suggestions for more analytical work in urban morphology', Teaching Geography, 7(3), 111-115.

Brainport Development (2015) Brainport Next Generation ( http://www.brainport.nl/en/ ) accessed 15 April 2016.

BVR. (2014a) MIRT onderzoek 20202040, Gebiedsvisie Brainportcity (BVR, Rotterdam).

BVR. (2014b) MIRT-onderzoek Brainport Avenue 2020-2040 (BVR, Rotterdam)

Camagni, R., Capello, R. \& Caragliu, A. (2015) 'Agglomeration economies in large versus small cities: similar laws, high specificities', in: Kourtit, K.; Nijkamp \& Stough, R. (ed.) The rise of the city. Spatial dynamics in the 
urban century (Edward Elgar Publishing, Cheltenham) 85-117.

Christiaanse, C., Schüller, N. \& Wollenberg, P. (2009) Urban Reports. Urban strategies and visions in mid-sized cities in a local and global context (gta Publishers, Zürich).

Conzen, M.R.G. (1981) 'The morphology of towns in Britain during the industrial era', in: Whitehand, J.W.R. (ed.) The urban landscape: historical development and management (Academic Press, London / New York)

Conzen, M.P. (2004) 'Appendix A. Glossary of Conzenian Technical Terms in Urban Morphology', in: Conzen, M.P, (ed) Thinking about Urban Form. papers on Urban Morphology (Peter Lang AG, Bern) 239-261.

Conzen, M.R.G. (2004) 'Appendix C: Notes on Urban Morphology', in: Conzen, M.P. (ed) Thinking about urban form. Papers on urban morphology 1932-1998 (Peter Lang AG Bern) 268-283.

Conzen, M.R.G. (2004) 'Morphogenesis, morphological regions, and secular human agency in the historic townscape, as exemplified by Ludlow', in: Conzen, M.P. (ed) Thinking about urban form. Papers on urban morphology 1932-1998 (Peter Lang AG Bern) 116-142.

Corboz, A. (1992) 'De stedebouw van de 20ste eeuw: een profiel', Archis, 49-52.

Davidson, M. and Lees, L. (2010) 'New-build gentrification: its histories, trajectories, and critical geographies', Population, Space and Place 16, 395-411.

De Zwart, B. (2007) 'Waar flaneren tot kunst verheven is. De rol van citybranding bij de herbestemming van Strijp S', unpublished master thesis, University of Technology Eindhoven.

Dehaene, M.; Havik, K.; Keunen, B.; Notteboom, B.; Uyttenhove, P.; Verraest, S.; Verschaffel, B. (2011) 'Mid-size city: The dual nature of urban imaginary in Europe during the long 20th century', introduction text of eponymous conference, Ghent.

European Committee (2016) Environment, Natura $2000 \quad$ (http://ec.europa.eu/ environment/nature/natura2000/index_ en.htm), accessed 28 February 2016.
European Union (2011) Cities of tomorrow. Challanges, visions, ways forward (European Union, Brussels).

Gemeente Eindhoven

Interimstructuurvisie 2009 (Gemeente Eindhoven, Eindhoven).

Glaeser, E. and Saiz, A. (2003) 'The rise of the skilled city', Working Papers, Federal Reserve Bank of Philadelphia, USA

$\mathrm{Gu}$, K. (2014) 'Morphological processes, planning, and market realities', in: $P$. Larkham, P. and Conzen, M.P. (ed.) Shapers of urban form. Explorations in morphological agency (Routledge, New York) 267-284.

Hamers, D. and Nabielek, K. (2006) Bloeiende bermen. Verstedelijking langs de snelweg (NAi publishers. Rotterdam).

Hauben, T., Vermeulen, M. \& Boer, F., 2007. Ruimtelijke scenario's voor de Brainport, Rotterdam: Urban Affairs \& VHP.

Hoogstra, G., Van Dijk, J. and Florax, R. (2005) 'Do jobs follow people or people follow jobs? A meta-analysis of Calino-Mills studies', paper presented at 45th Congress of the European Regional Science Association: "Land Use and Water Management in a Sustainable Network Society", Amsterdam, The Netherlands.

Janssen, J. (2010) 'Glanzende scherven in een zee van groen: de ruimtelijke transformatie van industriële mainport tot kennisintensieve brainport', in: Bosma, J. and Kolen, J., (ed.) Geschiedenis en ontwerp. Handboek voor de omgang met cultureel erfgoed (Vantilt, Nijmegen) 360-375.

Kalb, D. (1998) Expanding class: power and everyday politics in industrial communities, The Netherlands 1850-1950 (Duke University Press, Durham).

Lammers, D., Pereira Roders, A.; Van Wesemael, P. (2016) 'Radial fringe belt formation', paper presented at the 22nd ISUF Conference: City as organism. New visions for urban life, Sapienza Università di Roma, Italy

Larkham, P. (2000) 'Institutions and urban form: the example of universities' Urban Morphology 4(2), 63-77.

Larkham, P. and Jones, A. (1990) ISUF Glossary (http://www.urbanform.org/ glossary.html) accessed 20 February 2016. 
Larkham, P. and Morton, N. (2011) 'Drawing lines on maps: morphological regions and planning practices', Urban Morphology 15(2), 133-151.

Lebesque, S. and Gieskes, V. (2011) Joan Busquets. The city in layers (Architectura \& Natura, Amsterdam).

Mahsud, A., Moulaert, F.; Servillo, L. (2010) 'Prospective Urbaine - Exploring Urban Futures, background paper and questionnaire', Urban Futures workshop Leuven, Belgium.

Metaal, S. (2007) 'Gentrification, an overview', OASE Journal for Architecture 73, 7-28.

Ministerie van Infrastructuur en Milieu (2012) Structuurvisie infrastructuur en ruimte. Nederland concurrerend, bereikbaar, leefbaar en veilig (Ministerie van Infrastructuur en Milieu, The Hague).

Provincie Noord-Brabant (2014) Structuurvisie 2010 - partiële herziening 2014 (Provincie Noord-Brabant, 's Hertogenbosch).

Scheer, B.C. (2001) 'The anatomy of sprawl', Places 14(2), 28-37.

Scheer, B.C. (2013) 'The master plan is dead: long live urban morphology', Urban Morphology 17(1), 48-50.

Schuiling, D. (1996) 'Key projects for urban regeneration: the Dutch experience', Planning Practice \& Research 11(3), 279290.

Secchi, B. (2004) Diary of a planner (http:// www.planum.net/document-1) accessed 3 January 2010.

Secchi, B. and Viganò, P. (2009) Antwerp: territory of a new modernity (SUN, Amsterdam).

Van Boom, N. and Mommaas, H. (2009) Comeback cities. Vernieuwingsstrategieën voor de industriestad (NAi Publishers, Rotterdam).

Van den Brink, G. (1996) De grote overgang. Een lokaal onderzoek naar de modernisering van het bestaan. Woensel 1670-1920 (SUN, Nijmegen).

Van Gijzel, R. (2015) 'Nieuwjaarstoespraak 2015', official New Year's Speech of the mayor of Eindhoven, The Netherlands.

Van Gijzel, R. (2016) 'Nieuwjaarstoespraak 2016', official New Year's Speech of the mayor of Eindhoven, The Netherlands.
Van Winden, W.; De Carvalho, L.; Van Tuijl, E.; Van Haaren, J.; Van den Berg, L. (2012) Creating knowledge locations in cities (Routledge Abingdon, Oxford).

Whitehand, J.W.R. (1988) 'Urban fringe belts: development of an idea', Planning Perspectives 3(1), 47-58.

Whitehand, J.W.R. and Morton, N.J. (2004) 'Urban morphology and planning: the case of fringe belts', Cities 21(4), 275-289.

Zandbelt, D. (2011) 'Mid-size Utopia', LayOut (Stimuleringsfonds voor Architectuur, Rotterdam). 